\title{
MENGENAL BLENDED LEARNING
}

\author{
Oleh: M.Yusuf T.*
}

\begin{abstract}
Learning model will go on developing in line with the innovation of technology of education. The traditional learning model will be left behind in order to keep up with students demand. The Blended Learning model is one of the models that may answer the demand of education technology. Terminologically, Blended Learning is relatively new to a higher education, even in a company. Despite this, Blended Learning is a combination of a number of models or teaching methods. This paper will deeply discuss the definition, strengths and weaknesses, the development and some obstacles of this model.
\end{abstract}

KEYWORDS: learning model, blended learning, technology.

SEBELUM lebih jauh membicarakan blended learning (pembelajaran bercampur), ada baiknya sedikit mengulas electronic learning atau e-learning (pembelajaran elektronik) yang menjadi basisnya. Ada berbagai variasi definisi e-learning, salah satu yang sederhana dikemukakan oleh William Horton; is the use of information and computer technologies to create learning experiences $^{1}$ (adalah penggunaan teknologi informasi dan komputer untuk menciptakan pengalaman belajar). Defenisi ini menunjukkan bahwa dengan e-learning memungkinkan pembelajar untuk secara bebas memformulasi, mengorganisasi dan menciptakan pengalamannya melalui teknologi.

Selanjutnya, Horton menyebut beberapa model e-learning, ${ }^{2}$ antara lain; standalone courses, virtual-classroom courses, learning games and simulations, embedded e-learning, mobile learning, blended learning (BL), dan knowledge management. Setiap model memiliki kekhasan, namun semuanya memanfaatkan alat elektronik sebagai pendukung dalam implementasinya. BL yang menjadi fokus pembahasan tulisan ini, dipilih karena dianggap sebagai pendekatan paling tepat memoderasi kebutuhan pembelajaran masyarakat yang terbuka terhadap perubahan global sekaligus memenuhi selera belajar tradisional yang belum bisa ditinggalkan karena masih strategis dan efektif dalam mencapai tujuan-tujuan belajar.

*Kandidat Doktor bidang Teknologi Pendidikan pada Program Pascasarjana Universitas Negeri Jakarta ini adalah Dosen Tetap Fakultas Tarbiyah dan Keguruan UIN Alauddin Makassar. 
Secara konseptual, BL masih diperdebatkan. Jay Cross, ${ }^{3}$ dalam mengantar buku The Handbook of Blended Learning, secara sinic menyebutnya sebagai useless concepts, karena meragukan dampak pendekatan itu secara faktual terhadap hasil belajar. Sekalipun demikian, berbagai riset menunjukkan pendekatan ini cepat atau lambat akan menggantikan model pembelajaran tradisional karena terjadi percepatan ganda dalam cara anak didik memenuhi kebutuhan belajarnya sebagai akibat dari percepatan inovasi teknologi dalam bidang pendidikan.

Adopsi luas dan ketersediaan teknologi pembelajaran digital mendorong integrasi elemen-elemen pembelajaran berbantuan komputer dengan F2F. Jika diperhatikan, trendnya semakin hari menunjukkan perkembangan ke arah dimana blended akan mendapat proporsi lebih besar dan akan menggantikan model belajar tradisional an sich "chalk and talk".

\section{DEFINISI}

Secara etimologis, berasal dari kata blend yang berarti mix together. BL secara terminologis relatif masih baru dalam pendidikan tinggi ataupun dalam korporasi. Graham ${ }^{4}$ menyebutkan tiga defenisi yang paling sering dikemukakan: 1) defenisi yang mengkombinasikan berbagai modalitas media pembelajaran seperti dikemukakan oleh Bersin \& Associates, Orey, Singh dan Reed, serta Thompson, 2) defenisi yang mengkombinasikan berbagai metode-metode pembelajaran seperti dikemukakan oleh Driscoll, House dan Rossett, dan, 3) defenisi yang mengkombinasikan antara pembelajaran online dengan face-to-face, oleh Reay, Rooney, Sands, Ward \& LaBranche, dan Young.

Kelompok pertama menghubungkan antara berbagai instrumen media yang dapat digunakan dalam pembelajaran atau pelatihan. Media itu bisa berupa alat-alat teknologi, aktivitas ataupun tipe-tipe kegiatan yang dipilih untuk optimalisasi suatu program terhadap peserta tertentu. ${ }^{5}$ Ke-lompok kedua tidak mengemukakan batasan-batasan esensial dari BL, namun menyebutkan keterkaitan diantara metode-metode pembelajaran yang berbeda-beda untuk suatu kegiatan. Blend metode lebih variatif dimungkinkan karena kebutuhan belajar individu semakin beragam sehingga BL dapat dilihat sebagai bentuk dan evolusi paling logis dan alami dari cara pembelajaran dilangsungkan. ${ }^{6}$ Kelompok defenisi ketiga lebih akurat menunjukkan batasan pengertiannya dimana BL adalah integrasi diantara pembelajaran tatap muka dengan pembelajaran berbantuan komputer.

Rossett dan Frazee $^{7}$ menyimpulkan tiga kelompok defenisi tersebut dengan mengatakan: seemingly opposite approaches, such as formal and 
informal learning, face-to-face and online experiences, directed paths and reliance on selfdirection, and digital references and collegial connections, in order to achieve individual and organizational goals. Sementara survey yang dilakukan Sloan memberi defenisi berdasarkan proporsi kebutuhan online atas konten sumber. Menurutnya, proporsi antara 1 hingga 19\% belum bisa dikategorikan BL atau hybrid. Disebut BL jika proporsi kebutuhan akan sumber online berada di antara 20\% - 79\%. (Selengkapnya, lihat gambar 2). ${ }^{8}$

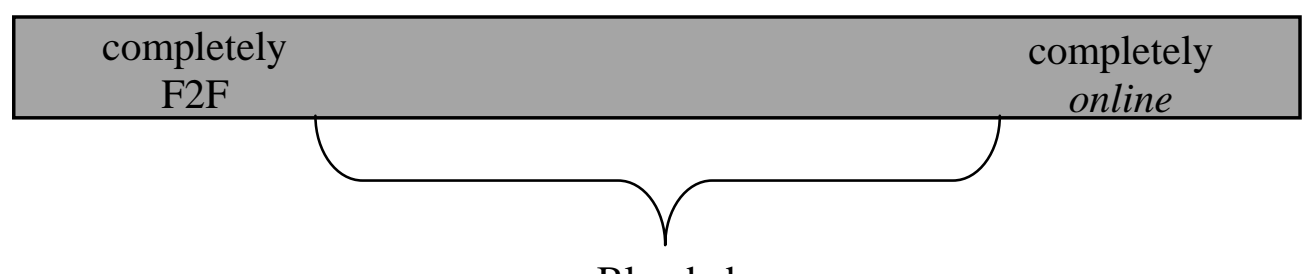

Blended

Gambar 1: posisi BL dalam pembelajaran

BL sering digunakan untuk makna yang sama dengan istilah hybrid dan mix-learning. Tiga istilah ini secara praktis mengkonvergensi bahanbahan elektronik dengan interaksi di dalam kelas. Pendekatan Ini menjadikan pembelajaran lebih personal dengan pemberian instruksi yang berbeda antara satu peserta dengan peserta yang lain (Lihat gambar 1).

Dari berbagai defenisi yang dikemukakan, dapat disimpulkan bahwa pengertian BL meliputi:

1. Integrasi antara F2F dan online learning untuk membantu pengalaman kelas dengan mengembangkan inovasi teknologi informasi dan komunikasi.

2. Suatu pembelajaran yang menggabungkan antara online dan F2F, proporsi online diperuntukkan untuk menyampaikan content yang secara tipikal menjadi bahan diskusi dan sebagainya untuk F2F. Konsorsium Sloan menyebutkan persentase online sekitar 30\% dan selebihnya, 70\% F2F. efektif dan efisien dengan mereduksi waktu belajar.

3. Kombinasi berbagai pendekatan dalam pembelajaran memungkinkan sumber-sumber virtual dengan sumber-sumber fisik. Sebagai catatan, BL haruslah dilihat sebagai pendekatan pedagogi yang mengkombinasi antara efektivasi dan peluang sosialisasi kelas yang secara teknologi mendorong pembelajaran aktif (active learning). Dalam pengertian lain, BL harusnya tidak hanya pada konstruksi belajar temporal, tetapi secara fundamental mendesain ulang model instruksional yang mengikuti bermacam karakteristik.

4. Suatu peralihan dari teacher centered ke student centered sehingga siswa menjadi lebih aktif dan interaktif. 
5. Menambah interaksi antara siswa dengan instruktur, siswa dengan siswa, siswa dengan konten belajar, dan siswa dengan sumber-sumber lain.

6. Integrasi antara mekanisme penilaian formatif dan sumatif baik bagi siswa maupun bagi instruktur. Lebih penting lagi bahwa BL merepresentasikan suatu pergeseran strategi pembelajaran. Kalau online learning hanya merupakan pengalihan model ke distance learning, maka BL secara signifikan memungkinkan merubah cara guru dan para administrator melayani pembelajaran online dalam setting F2F.

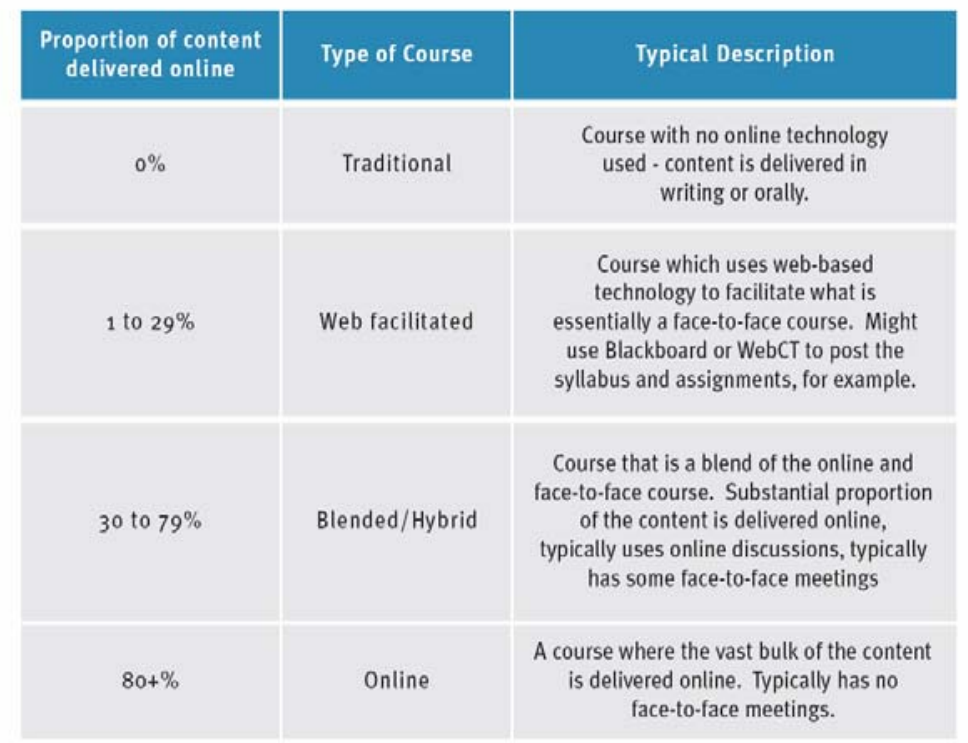

Gambar 2: Sloan survey definitions

\section{KELEBIHAN DAN KELEMAHAN F2F DAN E-LEARNING}

Seperti disebutkan sebelumnya bahwa antara F2F dan e-learning terfasilitasi secara mix dalam BL. Masing-masing memiliki kekuatan dan kelemahan sehingga jika dikombinasi maka berpotensi untuk saling menguatkan dan menutupi kelemahannya. Graham ${ }^{9}$ mengkategorisasi kekuatan dan kelemahan keduanya sebagai berikut;

Kekuatan e-learning: 1) flexibility: artinya siswa dapat berkontribusi dalam diskusi pada waktu dan tempat yang mereka pilih secara individual; 2) participation: bahwa semua siswa dapat berpartisipasi di dalam proses belajar karena mereka dapat mengatur waktu dan tempat untuk ikut serta; 3) depth of reflection: pembelajar memiliki waktu lebih banyak sehingga dapat lebih berhati-hati dalam berargumentasi serta lebih dalam merefleksikan pandangan dan pendapatnya. 
Kelemahannya adalah: 1) spontaneity: karena kecepatan ide dan pendapat yang dikemukakan umumnya tidak didukung oleh keruntutan berpikir sehingga pikiran-pikiran yang mengemuka tidak memiliki pondasi yang saling mendukung; 2) procrastination: ada tendensi procrastinasi; 3) human connection: ini kelemahan utamanya karena media bersifat impersonal untuk banyak orang.

F2F kekuatannya adalah: 1) human connection: lewat F2F sangat mudah membangun dan mengembangkan suatu presensi sosial dan rasa saling percaya; 2) spontaneity: melalui pembelajaran langsung, memungkinkan setiap orang untuk mengikuti dan mengimbangi percepatan berpikir diantara kontributor sehingga dimungkinkan mencapai kesepahaman. Kelemahannya adalah: 1) participation: ada hambatan-hambatan partisipasi untuk semua orang terutama jika terjadi dominasi perseorangan; 2) flexibility: karena katerbatasan waktu hingga memungkinkan suatu materi yang didiskusikan tidak mencapai sasaran yang diharapkan.

\section{PERKEMBANGAN MIX-LEARNING}

Penggunaan teknologi elektronik dalam pembelajaran sebenarnya adalah perkembangan logis dari temuan alat-alat yang mempermudah pekerjaan sehari-hari umat manusia. Temuan mungkin adalah yang paling jenius, tetapi pembelajaran di dalam kelas (didaktik) dan model tradisional Sokrates yang sejak tahun 1800-an telah menggunakan berbagai macam teknologi adalah temuan paling revolusioner merubah peradaban manusia. Hofman ${ }^{10}$ menyebut variasi alat yang telah memotong jaman (cutting edge) sejak diperkenalkannya tersebut adalah:

- 1450 - johannes Guttenberg memperkenalkan mesin ketik pertama kali

- 1840 - belajar dengan korespodensi pertama kali dilakukan (program sekretaris yang fokus pada pengajaran shorthand)

- 1900-an - audio recordings ditemukan

- 1920-an - stasiun radio

- 1930-an - televisi

- 1960-an - satelit

- 1960-an - Pre-World Wide Web Internet (text-based database and discussion boards)

- 1980-an - fiber optic, audiovisual tech/CD-ROM

- 1900-an hingga sekarang - World Wide Web

Alat-alat teknologi di atas yang demikian besar berpengaruh terhadap pembelajaran. Sejak teknologi gambar bergerak ditemukan, ada gairah bahwa aktivitas kelas akan semakin efisien sekalipun dalam ke- 
nyataannya hingga kini kita masih tetap menggunakan metode belajar tradisional lebih banyak dari sebelumnya. Efisiensi itu dapat dilihat pada kemungkinan seorang guru yang imajinatif dapat menggunakan berbagai teknologi untuk mengkombinasikan pembelajaran di dalam kelasnya (lihat gambar 2).

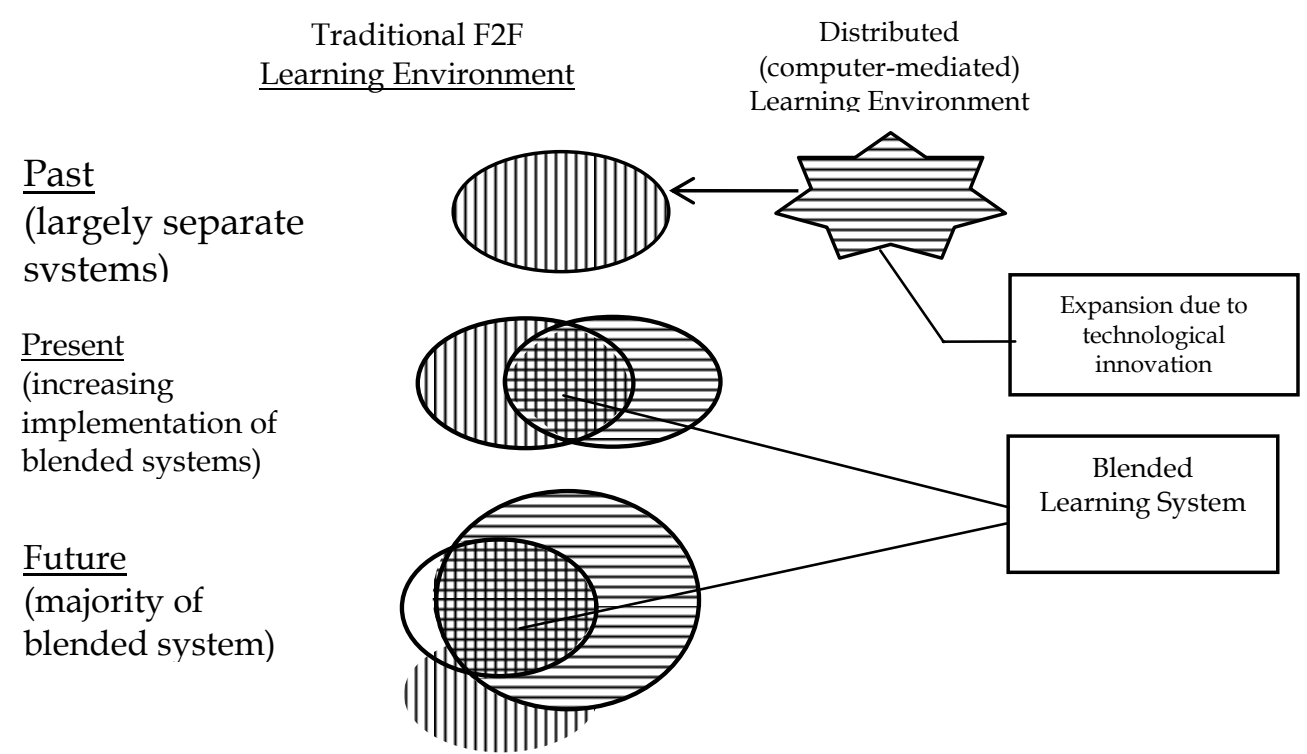

Gambar 2: Peta Perkembangan Konvergensi F2F dengan BL

Pada fase pertama, dukungan itu berlangsung secara terpisah sehingga lingkungan belajar murni berlangsung secara tradisional (F2F). Meskipun demikian, teknologi komputer telah diinovasi dan mulai diperkenalkan dalam lingkungan pembelajaran. Pada fase kedua, atau masa sekarang, antara lingkungan pembelajaran tradisional dan lingkungan pembelajaran terdistribusi mengalami pembauran sistemik dan terus menerus menunjukkan trend pengembangan yang seimbang dengan pendekatan pengajaran tradisional.

Jika trendnya diperhatikan, tampak jika semakin cepat inovasi atas teknologi pembelajaran digital maka akan semakin cepat adopsi BL ke dalam sistem belajar. Apa yang terjadi sekarang sesungguhnya adalah konsekuensi logis dari percepatan inovasi tersebut dalam 50 tahun terakhir. Ke depannya, percepatan integrasi elemen-elemen pembelajaran berbantuan komputer ke dalam F2F akan mendorong percepatan konvergensi dimana sistem BL akan diadopsi secara lebih terbuka bahkan akan lebih dominan.

Keadaan tersebut dipengaruhi oleh karakter BL yang lebih efisien dan menjanjikan efektifitas belajar lebih baik. Graham menjelaskan interseksi diantara kenyataan virtual dan kenyataan fisikal akan menempatkan 
BL sebagai strategi pembelajaran yang tidak bisa ditolak. Masie and Massy ${ }^{11}$ menyebutkan adopsi BL di Eropa telah menjadi kebijakan politik sejak PD II berakhir dan ICT sejak itu telah terintegrasi di dalam sistem pendidikan. Keduanya memprediksi dalam perkembangan pembelajaran di Eropa ke depan, yang disebut learning adalah blended learning.

Sloan melakukan survey terhadap 994 chief academic officers institusi publik (profit dan non-profit) di Amerika, hasilnya menunjukkan semua sekolah cenderung menggunakan variasi paradigma belajar dari pada menerapkan hanya belajar secara online (OL). Persentasi sekolah yang mengkombinasi sistem OL dan BL sangat dominan lebih dari 80\% daripada sekolah yang hanya mengimplementasi salah satu sistem saja. Survey ini juga menunjukkan bahwa lebih dari separuh sekolah di Amerika telah mengadopsi BL sebagai sistem belajar. (selengkapnya, lihat tabel 1)

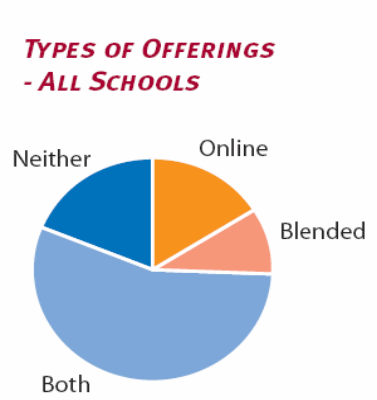

\section{Online and Blended Learning Go Together}

All schools are more likely to offer a variety of learning paradigms rather than offering only online courses. Instead of offering only online courses or only blended courses, over $80 \%$ of Public institutions offer both online and blended courses (see definitions above). This compares to $12.5 \%$ offering only online courses and $3.8 \%$ offering only blended courses. This pattern is true for Private, nonprofit schools as well. However, Private, forprofit schools are equally likely to offer only online courses and a combination of both online and blended courses.

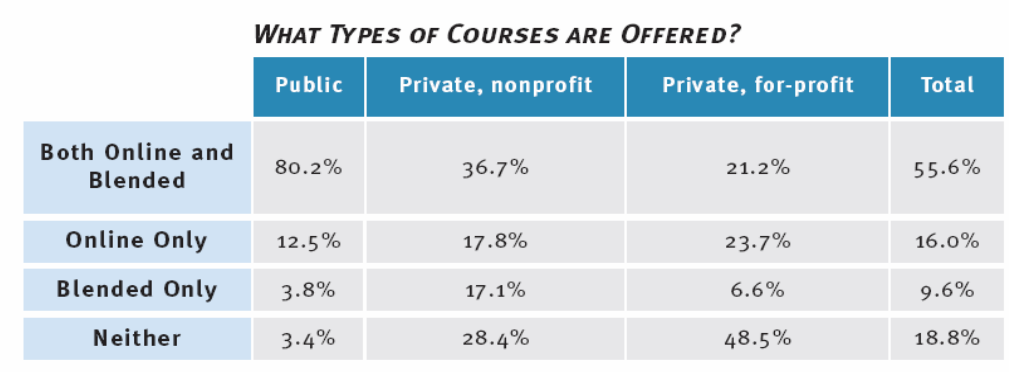

Tabel 1: Sumber data: http://weblearning.psu.edu/blendedlearning-initiative/conferences-trainings-and-resources

\section{MODEL BLENDED LEARNING}

Terdapat dua pendekatan BL yang dipraktekkan berbagai lembaga, baik perguruan tinggi ataupun perusahaan. Pertama adalah supplemental or 
enhancement model. Pendekatan ini mempertahankan struktur dasar pembelajaran atau pelatihan tradisional termasuk tatap muka dan textbook serta aktivitas luar kelas secara teknologi. Model kedua, mereduksi berbagai aktifitas pertemuan dalam kelas menggantikannya dengan out-of-class, online, aktifitas belajar secara interaktif dan membuat perubahan signifikan pada pertemuan in-class. Model kedua ini disebut juga replacement model.

Pada model pertama, pembelajaran relatif berlangsung secara elektronik sekalipun masih dalam koridor blended dengan F2F yang disimulasikan secara elektronik. Pendekatan ini lebih mendekati distance learning yang murni elektronik. Bersin ${ }^{12}$ menyebut model ini dengan frogram flow model. Model ini pertama-tama sacara bertahap menciptakan kurikulum yang mengintegrasikan berbagai media ke dalam suatu program yang berurutan (chronological) atau ke dalam silabus. Program ini menganalogikan proses-proses pembelajaran kelas dan setiap bagian atau langkah ke dalam rangkaian yang serasi dimana suatu tahapan merupakan kelangsungan dari tahapan sebelumnya. Program ini memuat outline yang jelas dan memudahkan pembelajar menyerap materinya secara linear. Pada akhir program, berisi latihan-latihan atau soal-soal untuk mengukur capaian pembelajaran secara total (Lihat gambar 3).

\begin{tabular}{|c|c|c|c|c|c|c|}
\hline $\begin{array}{c}\text { Kickoff } \\
\text { Event }\end{array}$ & $\begin{array}{c}\text { Initial } \\
\text { Learning } \\
\text { Activity }\end{array}$ & $\begin{array}{c}\text { Check in } \\
\text { Event }\end{array}$ & $\begin{array}{c}\text { Second } \\
\text { Learning } \\
\text { Activity }\end{array}$ & $\begin{array}{c}\text { Check in } \\
\text { Event }\end{array}$ & $\begin{array}{c}\text { Final } \\
\text { Assesment }\end{array}$ & $\begin{array}{c}\text { Feedback } \\
\text { and } \\
\text { Conclusion }\end{array}$ \\
\hline $\begin{array}{c}\text { The Process May Be Repeated } \\
\text { Several Times }\end{array}$ \\
\hline
\end{tabular}

Gambar 3: Program Flow Model

Model kedua lebih menekankan pada reduksi waktu belajar di dalam kelas dengan aktifitas luar kelas seperti online dan aktifitas interaktif lainnya tanpa meninggalkan F2F. Pendekatan ini dapat dilihat dalam "coreand-spoke" model. Pada model ini, desainer akan menciptakan suatu pendekatan pelatihan fundamental (biasanya onsite classroom atau web-based courseware) dan kemudian menyiapkan berbagai material, program-program interaktif, resources, dan assesment termasuk material pendukung. Pada model ini disiapkan berbagai exercises atau berbagai referensi secara multi media sekalipun tidak disusun detil step-by-step seperti halnya pada program flow model. 


\section{Tantangan Implementasi BL}

Dari pembahasan sebelumnya, tampak jelas bahwa BL fashionable dalam perkembangan pembelajaran dan pelatihan pada berbagai institusi masa kini. Namun demikian, patut dicatat beberapa hal penting kaitannya dengan implementasi BL; bagaimana desain kurikulumnya, desain sumber-sumber online yang digunakan, serta perubahan strategi belajar yang digunakan oleh siswa.

\section{Mendesain Kurikulum BL}

Model-model instruksional yang umum dikenal dalam pembelajaran F2F ternyata gagal digunakan untuk mencapai tujuan pembelajaran BL. Karena itu, pandangan Gagné tentang perbedaan instruksional untuk perbedaan hasil belajar (providing different instruction for different learning outcomes) perlu dikaji kembali guna menemukan desain instruksional BL yang tepat. Hal ini penting karena adanya hubungan yang sangat dekat antara proses mental internal pembelajar dengan aktifitas instruksional eksternal. Pengalaman implementasi BL di Cina ${ }^{13}$ (Huang dan Zhou) menunjukkan kombinasi antara ide Gagné dan kategori pengetahuan oleh Anderson cukup menjawab kebutuhan tersebut dan menghasilkan konsep "knowledge category and objective-oriented instruction" dan menset-up "instructional process modul of pan-knowledge" (aplikasinya, lihat tabel 2).

\begin{tabular}{|c|c|c|c|c|c|c|}
\hline \multirow{2}{*}{$\begin{array}{l}\text { Knowledge } \\
\text { Dimension }\end{array}$} & \multicolumn{6}{|c|}{ Cognitive Process Dimension } \\
\hline & Remember & Understand & Applay & Analyze & Evaluate & Create \\
\hline $\begin{array}{l}\text { Factual } \\
\text { Knowledge }\end{array}$ & \multirow{4}{*}{$\begin{array}{l}\text { Reading } \\
\text { (textbooks } \\
\text { and online } \\
\text { hyperteks) }\end{array}$} & $\begin{array}{l}\text { Tests; Search on } \\
\text { internet }\end{array}$ & & & & \\
\hline $\begin{array}{l}\text { Conceptual } \\
\text { Knowledge }\end{array}$ & & Concept map & Online test & & & \\
\hline $\begin{array}{l}\text { Procedural } \\
\text { Knowledge }\end{array}$ & & $\begin{array}{l}\text { Discussion; } \\
\text { Communication; } \\
\text { Concept } \\
\text { mappings; } \\
\text { Online } \\
\text { collaboration }\end{array}$ & $\begin{array}{l}\text { Practice; } \\
\text { Resolve } \\
\text { Well- } \\
\text { structured } \\
\text { problems }\end{array}$ & $\begin{array}{l}\text { Case } \\
\text { studies }\end{array}$ & Reflection & $\begin{array}{l}\text { Resolve ill- } \\
\text { structured } \\
\text { problems }\end{array}$ \\
\hline $\begin{array}{l}\text { Meta- } \\
\text { cognitive } \\
\text { Knowledge }\end{array}$ & & $\begin{array}{l}\text { Communication; } \\
\text { Brainstorming }\end{array}$ & $\begin{array}{l}\text { Making up } \\
\text { learning } \\
\text { strategy }\end{array}$ & $\begin{array}{l}\text { Activity } \\
\text { record } \\
\text { study }\end{array}$ & Reflection & \\
\hline
\end{tabular}

Tabel 2: Bidimensional Taxonomy of educational objectives and activity design. 


\section{Mendesain Sumber-Sumber Online}

Faktor penting dari kualitas penyelenggaraan BL kedua adalah variasi berbagai tipe media dan desain instruksional yang berbeda dengan sumber-sumber e-learning pada umumnya karena membutuhkan media yang lebih independent dan stable. Sumber-sumber BL yang dibutuhkan adalah sumber-sumber yang terintegrasi dengan aktifitas pembelajaran (khususnya aktivitas normal dalam kelas) dan menyatu di dalam sumbersumber kurikulum online. Dengan demikian, fleksibilitas BL tidak saja memfasilitasi pilihan pengetahuan dan pengembangan keterampilan, tetapi juga secara simultan mengembangkannya. Mendesain sumber-sumber BL lebih rumit karena sumber-sumber itu seharusnya bersesuaian dengan desain umum kurikulum, termasuk sumber-sumber baru yang harus adjust dengan aktivitas e-learning dan classroom.

\section{Strategi Pembelajaran BL}

Kualitas BL sangat ditentukan oleh strategi pembelajaran yang bersesuaian dengan minat peserta sehingga memotivasi mereka untuk mengikutinya secara optimal. Pilihan ini tidak semudah memilih strategi pembelajaran pada umumnya baik dalam pembelajaran online maupun F2F. Strategi pembelajaran BL secara umum adalah pengembangan strategi didaktik tradisional (lihat gambar 4). Studi e-learning di Korea terutama strategi pembelajaran online menunjukkan kelemahan signifikan yang tidak menguntungkan. Hal sama terjadi di China dan Malaysia, sekalipun BL masih lebih efektif dibandingkan dengan dua kutub lain, F2F dan OL.

\section{SIMPULAN}

Seperti kesimpulan Elliot Massie, e pada e-learning semestinya adalah blended. Artinya, tidak ada pembelajaran yang benar-benar lepas dari tradisi belajar tatap muka sehingga kombinasi diantara elektronik dengan tatap muka dalam pembelajaran adalah suatu keniscayaan. Kenyataan lain bahwa, hanya mengandalkan F2F tidak strategis lagi karena perkembangan revolusioner teknologi informasi dan komunikasi telah merasuk ke dalam nadi kehidupan sosial.

Mengimplementasikan BL dalam lembaga pendidikan membutuhkan treatment khusus yang mengkombinasi kebutuhan pembelajaran tradisional dengan pembelajaran elektronik dengan proporsi yang wajar. Tentu tidak mudah, banyak tantangan yang harus diperhatikan dengan seksama terutama desain programnya; kurikulum, sumber-sumber yang relevan, dan strategi pembelajaran. 


\section{CATATAN AKHIR}

1. William Horton, E-Learning by Design, San Fransisco: John Wiley \& Sons, CA, 2006, h. 1.

2. Ibid, h. 2.

3. Curtis J. Bonk and Charles R. Graham, The Handbook of Blended Learning; Global perspectives, Local Designs, San Francisco: John Wiley \& Sons, CA, 2006, h. 5.

4. Ibid, h. 24.

5. Josh Bersin, The Blended Learning Book; Best Practises, Proven Methodologies, and Lesson Learned, John Wiley \& Sons; San Francisco, CA., 2004, h. 2.

6. Kaye Thorne, Blended Learning, How to Integrate Online and Traditional Learning, Kogan Page; London, 2003, h. 5-6.

7. Allison Rossett dan Rebecca Vaughan Frazee, Blended Learning Opportunities, American Management Association, 2006, h. 2.

8. http://www.sloan-c.org/resources/survey.asp.

9. Curtis J.Bonk, et all, op cit, h. 27.

10. Dalam Curtis J.Bonk et all, op. cit, h. 35.

11. Ibid, h. 60.

12. Josh Bersin, op. cit, h. 21.

13. Lihat misalnya Curtis J.Bonk et all, op cit, h. 86.

\section{DAFTAR PUSTAKA}

Bersin, Josh, The Blended Learning Book; Best Practises, Proven methodologies, and Lesson learned, John Wiley \& Sons, San Francisco, CA, 2004.

Curtis J.Bonk, et all, The Handbook of Blended Learning; Global perspectives, Local Designs, John Wiley \& Sons, San Francisco, CA, 2006.

Horton, William, E-Learning by Design, John Wiley \& Sons, San Fransisco, CA, 2006.

Rossett, Allison, dan Rebecca Vaughan Frazee, Blended Learning Opportunities, American Management Association Special Report, 2006.

Thorne, Kaye, Blended Learning, How to Integrate Online and Traditional Learning, Kogan Page; London, 2003.

Watson, John, Blending Learning, The Convergence of Online and Face-to-Face Education, NACOL.

http://weblearning.psu.edu/blended-learning-initiative/conferences-trainingsand-resources

http://www.sloan-c.org/resources/survey.asp 